\title{
STUDENTS PERCEPTION OF REFERENCES IN DESCRIPTIVE TEXT
}

\author{
Deris Merdiawan Jamal ${ }^{1}$, Dian Ayu Bakta ${ }^{2}$, Ida Lisdawati \\ ${ }^{1}$ IKIP Siliwangi \\ ${ }^{2}$ IKIP Siliwangi \\ ${ }^{3}$ IKIP Siliwangi \\ ${ }^{1}$ Derismerdiawan76@gmail.com, ${ }^{2}$ Dian.ayu@gmail.com, ${ }^{3}$ Idalisdawati9088@gmail.com
}

\begin{abstract}
This research focuses on student perception about how to prepare to understand the use of types of references (anaphoric, cataphoric, and exophoric reference) in the Descriptive text. The objectives of this research are to find out what the types of references that many used in Descriptive text and how many types of references for all paragraph in Descriptive text. The method used in this research is a descriptive qualitative method. The researcher got the data from document analysis namely in the Descriptive text about Artikel. The result from this research are the result from the tenth paragraph of the Descriptive text that has already done to analysis, there are 6 anaphoric reference, 6 cataphoric and in this article contains an understanding of a text and a concept so students can understand about the material
\end{abstract}

Keywords: Reference, Types of Reference, Student Perceptions

\section{INTRODUCTION}

When considering student learning, a variety of theoretical perspectives focus on the contrast between the organization of knowledge as discrete, serial elements to be remembered and the integration and transformation of knowledge into a personally constructed meaningful entity. Wellington Road ( 2015 ) first made this distinction when he described approaches to learning in terms of either surface or deep processing of information, and this conceptualization has lead to much further theoretical development Clayton ( 2015). The deep approach involves an intention to gain personal understanding, with corresponding strategies to gain meaning from the learning task. This 'meaning' aspect is complemented by a structural aspect whereby information is organized by integrating the whole and the parts. The surface approach describes an intention to avoid failure with corresponding strategies that facilitate the memorization of facts without meaning and organization Neil Selwyn \& Rachel Aston in (Henderson, Selwyn, $\&$ Aston, 2017)references can found in written texts, such as short story, novel, advertisement, folklore, etc.

According to Luca Galatro in (Galatro, Mubarak, \& Spirito, 2016), The relationship between conceptions of learning, approaches to learning and learning outcomes is not, however, necessarily straightforward. discuss the apparent paradox in the relationship between conceptions of and approaches to learning, and the learning context, in so far as the literature suggests both that conceptions and approaches are stable yet they can be influenced by the learning environment. Marco Spirito in (Galatro et al., 2016) has developed an interactive systems model of teaching and learning to map how students' general conceptions of and approaches to learning interact with characteristics in the Considerable research now supports the various relationships posited in the model. For instance, some educational practices 
(presage) have been identified as encouraging surface learning strategies (process). In turn, research has also demonstrated that specific surface learning strategies (process) typically result in low-level learning outcomes (product), while deep learning strategies lead to cognitively complex performances Marco in (Galatro et al., 2016). Furthermore, when there are differences among students in their general approaches to learning (presage), changes to assessment procedures in a given situation (presage) will lead to changes for all students in their use of deep versus surface learning strategies in that situation (process), but the relative strength among students in their use of deep versus surface modes of operation will remain constant. Faisal Mubarak in (Galatro et al., 2016).

\section{METHOD}

The researchers used descriptive qualitative adopted from Michael Henderson in (Henderson et al., 2017) . The researchers use document analysis for collecting the data namely from the text of miss April. While, for analysis of the data, there were several steps in analyzing the data. First, the researcher chooses the descriptive text about someone. Second, analysis types of references used in each paragraph. Third, the researcher counting all types of references and determine what the types that many used for all paragraph in Descriptive text.

A descriptive qualitative was employed in this study to investigate the use of picture series in teaching writing. Referring to the objective of this study, the design is considered appropriate since it is a method used to describe or analyze the results of the study but not used for making broader conclusions according to Eva in (Shanti, ., \& Koto, 2018)

This study was conducted at Mts Nurul Hidayah Batujajar. The participants of this study were an English teacher and seventh-grade students of Mts Nurul Hidayah Batujajar. The data were obtained through classroom observation and interview. The lessons observed were writing lessons. During observations, the researcher was an observer and did not take part in any classroom activity. Field notes on the teacher's use of reading assessments were taken during each observation. The interviews were semi-structured The design of this study was classroom action research (CAR). Kemmis in (Apsari, 2017) stated action research is a form of collective self-reflection research conducted by participants - participants in social situations to improve educational practices and justice reasoning and their social practices as well as their understanding of their practices and against situations where such practices are performed In this experiment. modeled after Anneave and Olson (1967), subjects were trained to identify either haptic or tactual stimuli differing in up-down orientation. They were then tested for recognition with body orientation changed by $90 \mathrm{deg}$. The purpose was to determine whether subjects identified stimuli in terms of objective or body reference systems.

In studies of classroom order, Davies (1983in) has analyzed an instance of organizational talk in an elementary school classroom on the first day of school to show how students use their questions to acknowledge that they are hearing the teacher's description of the kind of teacher he wants to be and to hand him opportunities to elaborate his version. Paoletti (1990a, 1990b) has analyzed the organization of teacher-student talk in several classrooms at elementary, secondary and tertiary levels. She has observed how teachers and students achieve a workable classroom order through their conversation and interaction despite cross purposes and contradictions in their classroom descriptions.

\section{RESULTS AND DISCUSSION}

\section{Results}


Based on the data from document analysis of the Descriptive text about miss April the researcher got the result:

\section{Data 1}

Miss April is my English teacher in kindergarten and she teaches my class for a whole year.

Based on the data above, two references consist of anaphoric reference. Anaphoric reference exists in word $m y$ and she because the subject explained before the pronoun.

\section{Data 2}

Miss April wears square glasses and always cuts her hair short. She's very tall and very skinny.

Based on the data above, two references consist of anaphoric reference. Anaphoric reference exists in word her and she because the subject explained before the pronoun.

\section{Data 3}

She is very tall and very skinny. She says she doesn't like her skinny body but doesn't know how to gain weight either.

Based on the data above, two references consist of cataphoric reference. Cataphoric reference exists in a word she and her because the pronoun explained before the subject.

\section{Data 4}

She loves wearing sneakers to school, always wears a polo shirt and a pair of black pants.

Based on the data above, there is one reference that consists of cataphoric reference.

Cataphoric reference exists in a word she because the pronoun explained before the subject.

\section{Data 5}

Miss April has not married yet and doesn't have any children on her own.

Based on the data above, two references consists of anaphoric reference. Anaphoric reference exists in word miss April and her because the subject explained before the pronoun.

\section{Data 6}

\section{She says that's why she teaches kindergarten so that she can be near a lot of kids.}

Based on the data above, there is one reference that consists of cataphoric reference. Cataphoric reference exists in a word she because the pronoun explained before the subject. 


\section{Data 7}

She is a very smart and very fun teacher. She teaches us a lot of things from animals to house equipment.

Based on the data above, there is one reference that consists of cataphoric reference. Cataphoric reference exists in a word she because the pronoun explained before the subject.

\section{Data 8}

Miss April loves to play with us, she teaches us new words, how to spell the words that we just learn.

Based on the data above, two references consist of anaphoric reference. Anaphoric reference exists in word $u s$ and she because the subject explained before the pronoun.

\section{Data 9}

Sometimes she brings her ukulele to the class and sings us children songs, such as Itsy Bitsy Spider, Twinkle-Twinkle Little Star, and If You're Happy song.

Based on the data above, two references consist of cataphoric reference. Cataphoric reference exists in the word she and her because the pronoun explained before the subject.

\begin{tabular}{cll}
\hline Data & Sentences & Type of references \\
\hline 1 & $\begin{array}{l}\text { Miss April is my English teacher in kindergarten and } \\
\text { she teaches my class for a whole year }\end{array}$ & Anaphoric Reference \\
\hline 2 & $\begin{array}{l}\text { Miss April wears square glasses and always cuts her } \\
\text { hair short. She's very tall and very skinny. }\end{array}$ & Anaphoric Reference \\
\hline 3 & $\begin{array}{l}\text { She is very tall and very skinny. She says she doesn't } \\
\text { like her skinny body but doesn't know how to gain } \\
\text { weight either. }\end{array}$ & Cataphoric Reference \\
\hline 4 & $\begin{array}{l}\text { She loves wearing sneakers to school, always wears a } \\
\text { polo shirt and a pair of black pants }\end{array}$ & Cataphoric Reference \\
\hline 5 & $\begin{array}{l}\text { Miss April has not married yet and doesn't have any } \\
\text { children on her } \text { own. }\end{array}$ & Anaphoric Reference \\
\hline
\end{tabular}

$6 \quad$ She says that's why she teaches kindergarten so that Cataphoric reference she can be near a lot of kids.

$7 \quad$ She is a very smart and very fun teacher. She teaches Cataphoric Reference us a lot of things from animals to house equipment. 


\begin{tabular}{cll}
\hline 8 & $\begin{array}{l}\text { Miss April loves to play with } u s, \text { she teaches us new } \\
\text { words, how to spell the words that we just learn. }\end{array}$ & Anaphoric Reference \\
\hline & $\begin{array}{l}\text { Sometimes she brings her ukulele to the class and } \\
\text { sings us children songs, such as Itsy Bitsy Spider, } \\
\text { Twinkle-Twinkle Little Star, and If You're Happy } \\
\text { song. }\end{array}$ & Cataphoric Reference \\
\hline
\end{tabular}

\section{Discussion}

Based on the table above, it can be shown that Data 1 showed that two references consist of anaphoric reference. Anaphoric reference exists in word her and she because the subject explained before the pronoun.

And then Data 2 shows that two references consist of anaphoric reference. Anaphoric reference exists in word her and she because the subject explained before the pronoun.

In data 3 showed that two references consist of cataphoric reference. Cataphoric reference exists in the word she and her because the pronoun explained before the subject.

And data 4 Showed that there is one reference that consists of cataphoric reference. Cataphoric reference exists in word

In Data 5 two references consist of anaphoric reference. Anaphoric reference exists in word miss April and her because the subject explained before the pronoun.

And also data 6 , there is one reference that consists of cataphoric reference. Cataphoric reference exists in a word she because the pronoun explained before the subject.

In Data 7 there is one reference that consists of cataphoric reference. Cataphoric reference exists in a word she because the pronoun explained before the subject.

Data 8, two references consist of anaphoric reference. Anaphoric reference exists in word us and she because the subject explained before the pronoun.

Data 9 two references consist of cataphoric reference. Cataphoric reference exists in the word she and her because the pronoun explained before the subject.

At the researcher wrote at introduction this research objective to find out what the types of references that many used in Descriptive text and how many types of references for all paragraph in texts Descriptive. Based on the document analysis from the text, The writer got pieces of information about: what the types of references that many used in Descriptive text of miss April

The result from the tenth paragraph of this text have already done to analysis, there are 4 anaphoric references, 5 cataphoric references, . So, the types of reference that many used in the text miss April are anaphoric and cataphoric references 


\section{CONCLUSION}

Based on the result from analysis, the result from the nine paragraphs of the text Descriptive. that have already done to analysis, there are 4 anaphoric references, 5 cataphoric references. So, the types of references that many used in the text of Miss April are anaphoric and cataphoric references. And the total of the types of references in the text of Descriptive is 9 types of references.

\section{ACKNOWLEDGMENTS}

In the name of Allah, the beneficent, the merciful, All praises be to Allah, the lord of the world who has given the mercy and Blessing upon the writer in completing this article. Peace and salutation be upon the prophet Muhammad saw, his family and his companion, and his adherence

It is a pleasure to acknowledgment the help and contribution to all of the lecturer institution , family and friends who have contributed in different ways hence this " journal " is processed until it becomes a complete writing which will be presented to the faculty of IKIP SILIWANGI in a partial fulfillment of the degree of S.Pd in English education.

\section{REFERENCES}

Apsari, Y. (2017). The Use Of Picture Series In Teaching Writing Recount Text. Eltin Journal, Journal Of English Language Teaching In Indonesia, 5(2), 51. Https://Doi.Org/10.22460/Eltin.V5i2.P51-56

Galatro, L., Mubarak, F., \& Spirito, M. (2016). On The Definition Of Reference Planes In Probe-Level Calibrations. 87th Arftg Microwave Measurement Conference: Measurements For Emerging Communications Technologies, Arftg 2016. Https://Doi.Org/10.1109/Arftg.2016.7501968

Henderson, M., Selwyn, N., \& Aston, R. (2017). What Works And Why? Student Perceptions Of 'Useful' Digital Technology In University Teaching And Learning. Studies In Higher Education, 42(8), 1567-1579. Https://Doi.Org/10.1080/03075079.2015.1007946

Shanti, V. M.. S., \& Koto, I. (2018). Project-Based Learning Approach To Improve Students' Ability To Write Descriptive Text (A Classroom Action Research At Grade X Sman I Bengkulu Selatan). Joel (Journal Of Applied Linguistics And Literature), 1(2), 46-54. Https://Doi.Org/10.33369/Joall.V1i2.4196 